\title{
Cytogenetic Alteration Induced by Nickel and Chromium in Human Blood Cultures and its Amelioration by Curcumin
}

\author{
M. V. Rao, D. D. Jhala, A. Patel and S. S. Chettiar \\ Cytogenetics Division, Zoology Department, University School of Sciences, Gujarat University, \\ Ahmedabad 380 009, Gujarat, India \\ Telephone: 079-26302362, Fax: 079-26303196, E-mail: zooldeptgu@satyam.net.in
}

KEYWORDS Acrocentric association; telomeric association; C-anaphase; nickel; chromium; curcumin; blood cultures

\begin{abstract}
Tanners, welders and workers in various industries are exposed to acute and chronic toxicity of these heavy metals world wide. The present work is undertaken to evaluate the genotoxic effects of $\mathrm{Ni}$ and $\mathrm{Cr}$ at two different exposure intervals with a single dose and the amelioration of this toxicity using curcumin. $\mathrm{Ni}$ in form of nickel chloride $\left(4.216 \times 10^{-5} \mathrm{M}\right)$ and $\mathrm{Cr}$ as potassium dichromate $\left(1.36 \times 10^{-6} \mathrm{M}\right)$ were exposed for 24 and 69 hours to human blood lymphocyte cultures. The genotoxicity was measured by changes in acrocentric and telomeric association and $\mathrm{C}$-anaphase. Results revealed a significant positive correlation between DNA damage and exposure time in $\mathrm{Ni}$ and $\mathrm{Cr}$ added cultures alone. Likewise it was also observed in cultures with combination of both prooxidants. Groups supplemented with curcumin $\left(3.87 \times 10^{-7} \mathrm{M}\right)$ showed insignificant cytogenetic damage indicating its protective role which was calculated as percentage amelioration. Thus these data proved curcumin as a protective agent against $\mathrm{Ni}$ and $\mathrm{Cr}$ induced genotoxicity.
\end{abstract}

\section{INTRODUCTION}

Chromium $(\mathrm{Cr})$ and nickel $(\mathrm{Ni})$ are widely used industrial chemicals. The carcinogenic potential of metals is a major issue in defining human health risk from the exposure (Wenwei Hu et al. 2004). Welders, tanners and other occupationally exposed workers continue to suffer both acute and chronic health problems, which appear to be associated with exposure to $\mathrm{Ni}$ and $\mathrm{Cr}$ (Danadevi et al. 2004). Acute intoxications continue to be observed, consisting mostly of case reports of $\mathrm{Cr}$ intoxication related to bronchitis and pneumonitis from inhalation of welding fume (Coggon et al. 1994). Furthurmore, these metals are also known to induce SCEs and chromosomal aberrations in in vitro condition in human blood cultures (Rajvanshi et al. 2004).

$\mathrm{Ni}$ and $\mathrm{Cr}$ is known to induce DNA singlestrand breaks (SSBs) in human white blood cells (Jelmert et al. 1994) as well as cytogenetic damage in peripheral blood lymphocytes of $\mathrm{Ni}$ and $\mathrm{Cr}$-exposed workers (Stern et al. 1988; Knudsen et al. 1992; Danadevi et al. 2004). A recent hypothesis has postulated that oxidative stress may

Author for Correspondence: Dr. M. V. Rao

Professor \& Head Department of Zoology,

University School of Sciences,Gujarat University,

Ahmedabad 380 009, Gujarat. India

Telephone: 079-26302360 Fax: 079-26303196

E-mail: zooldeptgu@satyam.net.in arise as a result of imbalance between oxidants and antioxidants, which contribute to the genotoxic effects of $\mathrm{Ni}$ and $\mathrm{Cr}$ exposure (Anatoly et al. 2002). A dose and time dependent increase in frequency of micronuclei was observed in human lymphocyte culture by $\mathrm{Ni}$ and $\mathrm{Cr}$ suggesting the genotoxic effects of the heavy metals (Rao et al. 2007). Contrarily there was also finding that showed average SCE frequency for welders significantly lower than that for the control group and DNA-protein cross-links were also higher among the welders than among the controls (Popp et al. 1991; Costa et al. 1993).

Curcumin, a major yellow pigment and active component of turmeric powder extracted from Curcuma longa L. (Gingiberaceae), has been shown to possess anti-inflammatory and anticancer activities (Baek et al. 2003). Dietary antioxidants protect laboratory animals against the induction of tumors by a variety of chemical carcinogens. Among possible mechanism of protection against chemical carcinogenesis could be mediated via-antioxidant-dependent induction of detoxifying enzymes (Iqbal et al. 2003). Shishodia et al. (2003) showed pre-treatment with curcumin abolished the cigarette smoke induced genotoxic manifestations. Leu and Maa (2002) advocated the chemopreventive and antitumorigenic effect of curcumin by elucidating the effect of curcumin on certain proteins like aryl hydrocarbon receptor, cytochrome P450, glu- 
tathione S-transferase, serine/threonine kinases, transcription factors, cyclooxygenase, ornithine decarboxylase, nitric oxide synthase, matrix metalloproteinase and tyrosine kinases. Based on previous work in our laboratory, curcumin proved to be a strong protective agent against arsenic and fluoride induced genotoxicity (Rao and Tiwari 2006). Hence this study was undertaken to evaluate the role of this herbal product on heavy metal induced chromosomal aberrations in human blood cultures.

\section{METHODOLOGY}

Subjects: Venous blood was collected from healthy non-smoking individual, aging from 20 to 25 years old, with their consent, in sterile heparinised syringes. Detailed information regarding the pre exposure of individual to any kind of drugs or habitual insult was taken.

Peripheral blood lymphocyte culture (PBLC): Cultures were set-up for each individual according to the standard protocol of Perry and Wolff (1974). Seven ml of RPMI -1640 (Himedia, Mumbai, pH 7.4) already supplemented with fetal calf serum (FCS) (Himedia, Mumbai) 10\%, antibiotics (benzyl penicillin and streptomycin; Sarabhai Piramal Pharmaceuticals Ltd.,Vadodara. ) and 100- $\mu$ l phytohemagglutinin (PHA) $(5 \mathrm{mg} / 5 \mathrm{ml}$ distilled water; Sigma - Aldrich, USA), $0.5 \mathrm{ml}$ of blood were added. Toxicants were added at 0 hour and at 45 hour of incubation so as to expose the culture for 69 hour and 24 hour respectively.

At the $69^{\text {th }} \mathrm{hr}$., $30 \mu \mathrm{L}$ of colchicines $(1 \mathrm{mg} / 5 \mathrm{ml}$ distilled water; Himedia, Mumbai) was added for 30 minutes so that those cells, which have entered the dividing $\mathrm{M}$ phase, would be arrested at the metaphase stage of cell division. At $72^{\text {nd }}$ hour culture tubes were subjected to centrifugation at 1200 RPM for 15 minutes. The pellet obtained after centrifugation was treated with hypotonic solution (0.075 M KCl; Merck, Germany) for 20 min at $37^{\circ} \mathrm{C}$. These cells were then fixed by $1: 3$ aceto:methanol fixative and profusely flushed, and were given at least three washes of fixative.

Slides were prepared from the cell suspension obtained after two washes with fixative. These slides were then stained with $2 \%$ Geimsa stain (Himedia, Mumbai) and observed under the microscope at $100 \times$ for scoring acrocentric association and C-anaphase in 100 metaphase plates.

Groups Studied: Cultures were divided into eight groups. Group I was test control. While in
Group II curcumin alone was added $(10 \mu \mathrm{l} / 7 \mathrm{ml}$ media, 3.87 X 10-7 M; Himedia, Mumbai). Group III and Group IV were treated with $\mathrm{Ni}\left(\mathrm{NiCl}_{2} 4.216\right.$ X $10^{-5} \mathrm{M}$, Himedia, Mumbai $)$ and $\mathrm{Cr}\left(\mathrm{K}_{2} \mathrm{Cr}_{2} \mathrm{O}_{7 ;} 1.36\right.$ $\mathrm{X} 10^{-6} \mathrm{M}$; Himedia, Mumbai) respectively and Group V with a combination of the same concentrations of toxicants. Groups VI, VII and VIII were curcumin supplemented with $\mathrm{Ni}, \mathrm{Cr}$ and $\mathrm{Ni}+\mathrm{Cr}$. The positive control ethyl methyl sulfonate (EMS;Merck, Germany) was also done. Exposure intervals (24hr.and $69 \mathrm{hr}$.) remained same for all the test materials.

Analysis of Parameters: 100 Metaphase plates per group were analyzed under the microscope for association and C-anaphase. Percentage of amelioration was calculated by using the following formula: (Rao and Tiwari ; 2006)

(Pro-oxidant Group-Respective Antioxidant Group) / (Pro-oxidant Group - Control) $\times 100$

Statistical Analysis: The data was analysed using student's t-test. Results are expressed as mean $\pm \mathrm{SE}$. All the treated groups were compared with the control group, and the curcumin-supplemented groups were compared with their respective pro-oxidant groups. $\mathrm{P}$ values less than 0.05 were considered to be significant.

\section{RESULTS}

After $24 \mathrm{hrs}$. of exposures, cultures treated with nickel and chromium alone did not exhibit remarkable alteration in the acrocentric association, telomeric association and $\mathrm{C}$-anaphase as compared to control. Nickel + chromium added cultures showed a significant $(\mathrm{p}<0.001)$ increase in acrocentric and telomeric associations. However, cultures treated with combination of prooxidants showed no significant variation in $\mathrm{C}$ anaphase values. $\mathrm{Ni}$ and $\mathrm{Cr}$ alone and in combination with curcumin supplementation revealed $80 \%$ to $85 \%$ amelioration (Tables $1,3 \& 5$ ).

Prolonged exposure (69 hrs.) revealed that acrocentric association was significantly $(\mathrm{p}<0.01$, $\mathrm{p}<0.001$ ) increased in the cultures treated with $\mathrm{Ni}$ and $\mathrm{Cr}$ alone respectively (Table - 2), while telomeric association also exhibited a significant $(\mathrm{p}<0.05)$ alteration (Table 4). However $\mathrm{Ni}$ and $\mathrm{Cr}$ treated cultures exhibited no alterations in $\mathrm{C}$-anaphase values (Table 6). The combined groups $(\mathrm{Ni}+\mathrm{Cr})$ had a significant $(\mathrm{p}<0.001, \mathrm{p}<0.05, \mathrm{p}<0.05)$ increase in frequency of acrocentric association and telomeric associations as well as C-anaphase values 
respectively (Tables 2, $4 \& 6$ ). Curcumin co cultures with pro-oxidants after $69 \mathrm{hrs}$. exposure induced a reduction in all these indices showing amelioration from $66 \%$ to $91 \%$ (Tables $2,4 \& 6$ ).

\section{DISCUSSION}

The present data described the genotoxic effect of $\mathrm{Ni}$ and $\mathrm{Cr}$ in human blood cultures with

Table1: Effect of curcumin on $\mathrm{Ni}$ - and/or $\mathrm{Cr}$-induced acrocentric association in 100

\begin{tabular}{lrrrrrrrr}
\hline Groups & $D D$ & $D G$ & $G G$ & Multiple & Mean \pm SE & T- test & \% Amelieoration \\
\hline Control & 7.8 & 6.8 & 4.2 & 5.6 & 24.4 & \pm 0.73 & 0 & \\
Curcumin & 7.6 & 7.0 & 4.4 & 5.4 & 24.4 & \pm 0.73 & 0 & \\
Nickel & 8.2 & 7.4 & 4.8 & 6.0 & 26.4 & \pm 1.34 & $1.309^{\mathrm{ns}}$ & \\
Chromium & 8.6 & 7.8 & 5.0 & 6.2 & 27.6 & \pm 2.23 & $1.361^{\mathrm{ns}}$ & \\
Ni+Cr & 1.4 & 9.8 & 6.0 & 7.6 & 34.8 & \pm 1.53 & $6.102^{*}$ & \\
Ni+Cur & 8.0 & 6.8 & 4.6 & 5.4 & 24.8 & \pm 1.05 & $0.312^{\mathrm{ns}}$ & 80.0 \\
Cr+Cur & 8.0 & 7.0 & 4.4 & 5.6 & 25.0 & \pm 1.35 & $0.392^{\mathrm{ns}}$ & 81.3 \\
Ni+Cr+Cur & 8.0 & 7.0 & 5.0 & 6.0 & 26.0 & \pm 1.57 & $0.922^{\mathrm{ns}}$ & 84.6 \\
\hline
\end{tabular}

metaphase plates in Human lymphocyte cultures after 24-hr exposure $(n=5)$

$* \mathrm{p}<0.001$, ns non significant

Table2: Effect of curcumin on $\mathrm{Ni}$ - and/or $\mathrm{Cr}$-induced acrocentric association in 100 metaphase plates in human lymphocyte cultures after 69-hr exposure $(n=5)$

\begin{tabular}{|c|c|c|c|c|c|c|c|c|}
\hline Groups & $D D$ & $D G$ & $G G$ & Multiple & $\mathrm{Mea}$ & $n \pm S E$ & $T$ - test & $\%$ Amelieoration \\
\hline Control & 8.0 & 6.4 & 4.2 & 5.6 & 24.2 & \pm 0.70 & 0 & \\
\hline Curcumin & 7.8 & 6.8 & 4.4 & 5.6 & 24.6 & \pm 0.73 & $0.395^{\mathrm{ns}}$ & \\
\hline Nickel & 9.8 & 7.4 & 5.2 & 7.4 & 29.8 & \pm 1.55 & $3.288 *$ & \\
\hline Chromium & 11.0 & 8.0 & 6.4 & 8.2 & 33.6 & \pm 1.64 & $5.276 * *$ & \\
\hline $\mathrm{Ni}+\mathrm{Cr}$ & 13.0 & 9.2 & 7.2 & 9.0 & 38.4 & \pm 1.27 & $9.806 * *$ & \\
\hline $\mathrm{Ni}+\mathrm{Cur}$ & 8.2 & 6.6 & 4.4 & 5.8 & 25.0 & \pm 0.90 & $0.699^{\mathrm{ns}}$ & 85.7 \\
\hline $\mathrm{Cr}+\mathrm{Cur}$ & 9.0 & 7.4 & 4.4 & 5.8 & 26.6 & \pm 1.23 & $1.698^{\mathrm{ns}}$ & 74.4 \\
\hline $\mathrm{Ni}+\mathrm{Cr}+\mathrm{Cur}$ & 11.0 & 7.0 & 5.0 & 6.0 & 29.0 & \pm 1.32 & $3.216 *$ & 66.2 \\
\hline
\end{tabular}

$* \mathrm{p}<0.01, * * \mathrm{p}<0.001, \mathrm{~ns}$ non significant

Table 3: Effect of curcumin on $\mathrm{Ni}$ - and/or $\mathrm{Cr}$-induced telomeric association in 100 metaphase plates in human lymphocyte cultures after $24-h r$ exposure $(n=5)$

\begin{tabular}{|c|c|c|c|c|c|c|}
\hline Groups & Chromatid & Chromosomal & Mean & $\eta \pm S E$ & $T$ - test & $\%$ Amelieoration \\
\hline Control & 9.4 & 3.6 & 13.0 & \pm 0.76 & 0 & \\
\hline Curcumin & 9.6 & 3.6 & 13.2 & \pm 0.50 & $0.217^{\mathrm{ns}}$ & \\
\hline Nickel & 10.0 & 3.8 & 13.8 & \pm 1.41 & $0.496^{\mathrm{ns}}$ & \\
\hline Chromium & 10.2 & 4.0 & 14.2 & \pm 2.35 & $0.484^{\mathrm{ns}}$ & \\
\hline $\mathrm{Ni}+\mathrm{Cr}$ & 13.4 & 5.4 & 18.8 & \pm 1.20 & $4.059 *$ & \\
\hline $\mathrm{Ni}+\mathrm{Cur}$ & 9.6 & 3.6 & 13.2 & \pm 1.05 & $0.153^{\mathrm{ns}}$ & 75.0 \\
\hline $\mathrm{Cr}+\mathrm{Cur}$ & 9.8 & 3.4 & 13.2 & \pm 1.25 & $0.136^{\mathrm{ns}}$ & 83.3 \\
\hline $\mathrm{Ni}+\mathrm{Cr}+\mathrm{Cur}$ & 10.2 & 3.4 & 13.6 & \pm 1.53 & $0.35^{\mathrm{ns}}$ & 89.7 \\
\hline
\end{tabular}

$* \mathrm{p}<0.001$, ns non significant

Table 4: Effect of curcumin on Ni- and/or $\mathrm{Cr}$-induced Telomeric Association in 100 metaphase plates in Human lymphocyte cultures after 69-hr exposure $(n=5)$

\begin{tabular}{lcccccc}
\hline Groups & Chromatid & Chromosomal & Mean \pm SE & T-test & \% Amelieoration \\
\hline Control & 9.4 & 3.4 & $12.8 \pm \pm 0.72$ & 0 & \\
Curcumin & 9.6 & 3.4 & $13.0 \pm \pm 0.72$ & $0.1968^{\mathrm{ns}}$ & \\
Nickel & 11.0 & 4.0 & $15.0 \pm \pm$ & 1.55 & $1.2883^{\mathrm{ns}}$ & \\
Chromium & 12.4 & 5.4 & $17.8 \pm \pm 1.28$ & $3.40785^{*}$ & \\
Ni+Cr & 13.8 & 6.2 & $20.0 \pm \pm 1.86$ & $3.60321^{*}$ & 91 \\
Ni+Cur & 9.4 & 3.6 & $13.0 \pm \pm 1.04$ & $0.15847^{\mathrm{ns}}$ & 88 \\
Cr+Cur & 10.0 & 3.4 & $13.4 \pm \pm 1.30$ & $0.40372^{\mathrm{ns}}$ & 80 \\
Ni+Cr+Cur & 10.2 & 4.0 & $14.2 \pm \pm 1.38$ & $0.89891^{\mathrm{ns}}$ & 80 \\
\hline
\end{tabular}

$* \mathrm{P}<0.005$, ns non significant 
Table 5: Effect of curcumin on Ni- and/or $\mathrm{Cr}$-induced $\mathrm{C}$-anaphase in 100 metaphase plates in human lymphocyte cultures after24-hr exposure $(n=5)$

\begin{tabular}{lccclc}
\hline Groups & C- - Anaphase & Meanstd & error & T- test & \% Amelieoration \\
\hline Control & 0.6 & $0.6 \pm 0.40$ & 0 & \\
Curcumin & 0.6 & $0.6 \pm 0.24$ & 0 & \\
Nickel & 1.0 & $1.0 \pm \pm 0.63$ & $0.5345^{\mathrm{ns}}$ & \\
Chromium & 1.4 & $1.4 \pm 0.74$ & $0.9428^{\mathrm{ns}}$ & \\
$\mathrm{Ni}+\mathrm{Cr}$ & 2.0 & $2.0 \pm 0.70$ & $1.72328^{\mathrm{ns}}$ & \\
$\mathrm{Ni}+\mathrm{Cur}$ & 0.8 & $0.8 \pm 0.37$ & $0.36515^{\mathrm{ns}}$ & 50 \\
$\mathrm{Cr}+\mathrm{Cur}$ & 1.0 & $1.0 \pm 0.40$ & $0.70711^{\mathrm{ns}}$ & 50 \\
$\mathrm{Ni}+\mathrm{Cr}+\mathrm{Cur}$ & 1.2 & $1.2 \pm 0.58$ & $0.84853^{\mathrm{ns}}$ & 57 \\
\hline
\end{tabular}

ns non significant

Table 6: Effect of curcumin on $\mathrm{Ni}$ - and/or $\mathrm{Cr}$-induced $\mathrm{C}$-anaphase in 100 metaphase plates in human lymphocyte cultures after 69-hr exposure $(n=5)$

\begin{tabular}{|c|c|c|c|c|c|}
\hline Groups & $C$ - Anaphase & $M \epsilon$ & $a n \pm S E$ & $T$ - test & $\%$ Amelieoration \\
\hline Control & 0.8 & 0.8 & 0.58 & 0 & \\
\hline Curcumin & 0.6 & 0.6 & $\pm \quad 0.40$ & $0.28284^{\mathrm{ns}}$ & \\
\hline Nickel & 2.4 & 2.4 & $\pm \quad 0.93$ & $1.46059^{\mathrm{ns}}$ & \\
\hline Chromium & 3.6 & 3.6 & \pm 1.03 & $2.36643 \mathrm{~ns}$ & \\
\hline $\mathrm{Ni}+\mathrm{Cr}$ & 4.2 & 4.2 & 1.74 & $1.84936^{*}$ & \\
\hline $\mathrm{Ni}+\mathrm{Cur}$. & 1.2 & 1.2 & $\pm \quad 0.58$ & $0.48507^{\mathrm{ns}}$ & 75.0 \\
\hline Cr.+Cur & 1.4 & 1.4 & $\pm \quad 0.61$ & $0.71307^{\mathrm{ns}}$ & 78.5 \\
\hline $\mathrm{Ni} .+\mathrm{Cr} .+\mathrm{Cur}$. & 1.4 & 1.4 & $\pm \quad 0.51$ & $0.7746^{\mathrm{ns}}$ & 82.3 \\
\hline
\end{tabular}

$* \mathrm{p}<0.05$, ns non significant

respect to acrocentric satellite association, telomeric association and $\mathrm{C}$-anaphase. It is known that nickel (II) and chromium (III) enter the cell directly while $\mathrm{Cr}$ (VI) penetrates only by means of sulfate ion channel. After entering into the cell it converts into the stable form $\mathrm{Cr}$ (III) (Kerger et al. 1997). These Ni(II) and Cr(III) ions accelerate the formation of the free radicals which cause lipid peroxidation as well as DNA damage. These free radicals also inhibit the DNA repair enzymes followed by cell cycle regulatory enzymes proteins leading to low cell proliferation. Chromium and nickel compounds further interact with DNA repair processes that lead to an enhancement of genotoxicity in combination with a variety of DNA damaging agents (Klein et al. 1991; Kasprzak 1991). Millosevic et al. (2005) showed that the newborns exposed to environmental pollutant containing $\mathrm{Ni}$ and $\mathrm{Cr}$ illustrate high frequency of micronuclei, which supports our finding. Thus both metal compounds are potential in bringing about cytogenetic attrition inducing genotoxicity.

Telomeres protect the end of the chromosome against degradation, inappropriate recombination and fusion events. Telomeric shortening might lead to sticky ends which join to result into nondisjunction in forth coming cell division
(Blackburn 2001). Telomeric sequences are also lost with cell division alongwith other causes including oxidative stress (Von et al. 1995; Andrei and Peter 2003). In addition to loss of telomeric DNA with replication, oxidative damage of telomeric DNA is an important cause of the telomere shortening followed by telomeric association in normal human somatic cells (Saretzki 2002; Collins and Mitchell 2002). This acceleration was attributed to the enhanced induction of telomeric single strand breaks by free radicals, leading to the loss of the distal fragments of telomeric DNA following replication (Sitte et al. 1998). Other studies revealed that telomeric DNA is a preferential target for oxidative damage (Henle et al. 1999; Oikawa and Kawanishi 1999). Liu et al. (2002) reported arsenic induces telomeric association by enhancing the oxidative stress in the cells. Similarly our results supported an increased telomere association probably due to telomeric shortening in cultures added with prooxidants.

The fission of two or more nucleoli would tend to stretch mechanically the nucleolar forming chromosome segment with obvious risk of breakage. If breaks occur in more than one of the chromosomes involved the closeness of the broken ends would predispose to translocations and 
the acrocentirc satellite association (SA) would thus be active also in the origin of translocation between satellite chromosomes. A high incidence of SA as a result of any chemical insult has often been considered as causative to an increased tendency of nondisjunction and thus to the induction of $\mathrm{D}$ and $\mathrm{G}$ trisomies or structural aberration. The elevated frequency in acrocentric satellite association in our study, is attributed to the ability of pro-oxidants to induce DNA damage.

The appearance of $\mathrm{C}$-anaphase indicated the premature onset of anaphase in $\mathrm{Ni}$ and $\mathrm{Cr}$ arrested mitotic lymphocyte cells. Huang et al. (1998) demonstrated that heavy metals could interfere with the functions of mitotic spindles by attenuating the dynamics of tubulin and hence, induce mitotic arrest in HeLa cells. In our study, thses data demonstrated that $\mathrm{Ni}$ and $\mathrm{Cr}$ also likely block the onset of metaphase to anaphase transition, this inhibition could be due to spindle inactivation in pro-oxidant treated mitotic cells. Thereafter, the defective bipolar spindles would not allow completion of normal chromosome segregation and cytokinesis. To trigger the transition of metaphase into anaphase, the exit from mitosis and cytokinesis is generally known to be via the activation of APC/C, a multi-subunit complex with ubiquitin-ligase activity (Townsley et al. 1998), and by its association with activator proteins p55cdc 20 or cdh1 to form the APC/C $\mathrm{C}^{\text {cdc20 }}$ or APC/ $\mathrm{C}^{\text {cdh1 }}$ complex (Burke 2000) . The APC/ $\mathrm{C}^{\text {cdc20 }}$ complex is required for the onset of anaphase by triggering the proteolytic degradation of Pds 1 (Nasmyth et al. 2000), whereas the APC/C ${ }^{\text {cdhl }}$ complex is needed for cytokinesis and mitotic exit by complete degradation of mitotic cyclins (Visintin et al. 1997). The sequential activation of APC/ $\mathrm{C}^{\mathrm{cdc} 20}$ and $\mathrm{APC} / \mathrm{C}^{\mathrm{cdh} 1}$ plays a key role in establishing the temporal order of cell cycle control (Nigg 2001). Ni and Cr possibly hampered cell cycle regulation by directly interacting with these proteins and inducing an imbalance in cell cycle. Disruption of the temporal order of cell cycle progression might severely alter chromosome segregation and lead to loss of genomic integrity (Nigg 2001; Cerutti and Simanis 2000; Luch 2002).

Curcumin supplementation brought about protective effect on nickel and chromium induced genotoxicity, as the values of acrocentric association, telomeric association and $\mathrm{C}$-anaphase were comparable to control cultures. Its amelioration effect is related to possession of parahy- droxyl groups, which have antioxidant activity while other reactive groups like keto and double bonds of curcumin have anti mutagenic effects. Hence this herbal product scavenges and neutralizes free radical generated during toxic reactions in response to the chemical insult, by breaking their subsequent oxidative chain reactions (Das and Das 2002; Rajvanshi et al. 2004). In conclusion, curcumin proved to be a very strong protective agent against $\mathrm{Ni}$ and $\mathrm{Cr}$ induced genotoxic indices in our study.

\section{CONCLUSION}

To conclude, our study suggests that the curcumin had the potential ameliorative effect on nickel and chromium exerted genotoxicity in vitro.

\section{ACKNOWLEDGEMENT}

This work is supported by Univrsity Grants Commision (UGC) New Delhi to MVR.

\section{REFERENCES}

Anatoly Z, George Q, Joseph M, Zhanna M 2002. Reductive activation with cysteine represents a chromium (III)-dependent pathway in the induction by carcinogenic chromium(VI). EHP, 110: 729-731.

Andrei T, Peter ML 2003. Role of oxidative stress in telomere shortening in cultured fibroblasts from normal individuals and patients with ataxia-telangiectasia. Human Molecular Genetics, 12(3): 227232

Baek OS, Kang OH, Choi YA, Choi SC, Kim TH, Nah YH, Kwon DY, Kim YK, Kim YH, Bae KH, Lim JP, Lee YM 2003. Curcumin inhibits protease-activated receptor-2 and -4-mediated mast cell activation. Clin Chim Acta, 338(1-2): 135-141.

Blackburn EH 2001. Switching and signaling at the telomere. Cell, 106: 661-673.

Burke DJ 2000. Complexity in the spindle checkpoint. Curr Opin Genet Dev, 10: 26-31.

Cerutti L, Simanis V 2000. Controlling the end of the cell cycle. Curr Opin Genet Dev, 10: 65-69.

Collins K, Mitchell JR 2002. Telomerase in the human organism. Oncogene, 21: 564-579.

Costa M, Zhitkovich A, Toniolo P 1993. DNA-protein cross-links in welders: molecular implications. Cancer Research, 53: 460-463.

Danadevi K, Roya RB, Saleha B, Paramjit G 2004. Genotoxic evaluation of welders occupationally exposed to chromium and nickel using the Comet and micronucleus assays. Mutagenesis, 19: 35-41.

Das KC, Das CK 2002. Curcumin (diferuloylmethane) a singlet oxygen $\left(\mathrm{O}_{2}\right)$ quencher. Biochemical and Biophysical Research Communications, 295(1): 62-66

Henle ES, Han Z, Tang N, Rai P, Luo Y, Linn S 1999. 
Sequence-specific DNA cleavage by $\mathrm{Fe}^{2+}$-mediated fenton reactions has possible biological implications. J Biol Chem, 274: 962-971.

Huang SC, Lee TC 1998. Arsenite inhibits mitotic division and perturbs spindle dynamics in HeLa S3 cells. Carcinogenesis (Lond.), 19: 889-896.

Iqbal M, Sharma SD, Okazaki Y, Fujisawa M, Okada S 2003. Dietary supplementation of curcumin enhances antioxidant and phase II metabolizing enzymes in ddY male mice: possible role in protection against chemical carcinogenesis and toxicity. Pharmacol Toxicol, 92(1): 33-8.

Jelmert Ø, Hansteen IL, Langård S 1994. Chromosome damage in lymphocytes of stainless steel welders related to past and current exposure to manual metal arc welding fumes. Mut Res, 320: 223-233.

Kasprzak K 1991. The oxidative damage in metal carcinogenicity. Chemical Research in Toxicology, 4: 604-615.

Kerger BD, Finley BL, Corbet GE 1997. Ingestion of chromium (VI) in drinking water by human volunteers. Absorption, distribution and excretion of single and repeted doses. Journal of Toxicology and Environmental Health, 50: 67-95.

Klein CB, Frenkel K, Cost M 1991. The role of oxidative process in metal carcinogenesis. Chemical Research in Toxicology, 4: 592-603.

Knudsen LE, Biosen T, Christensen JM 1992. Biomonitoring of genotoxic exposure among stainless steel welders. Mut Res, 279: 129-143.

Leu TH, Maa MC 2002. The molecular mechanisms for the antitumorigenic effect of curcumin. Curr Med Chem Anti-Canc Agents, 2(3): 357-370.

Liu L, Trimarchi JR, Navarro P, Blasco MA, Keefe DL 2003. Oxidative stress contributes to arsenic-induced telomere attrition, chromosome instability and apoptosis. J Biol Chem, 278: 31998-32004.

Luch A 2002. Cell cycle control and cell division: implications for chemically induced carcinogenesis. Chembiochem, 3: 506-516.

Milosevic-Djordjevic O, Grujicic D, Arsenijevic S, Marinkovic D 2005. Monitoring of Lymphocyte Micronuclei among Newborns from Kragujevac in Central Serbia before and after Environmental Contamination. Tohoku Journal of Experimental Medicine, 205(1): 1-9.

Nasmyth K, Peters JM, Uhlmann F 2000. Splitting the chromosome: cutting the ties that bind sister chromatids. Science (Wash. DC), 288: 1379-1385.

Nigg EA 2001. Mitotic kinases as regulators of cell division and its checkpoints. Nat Rev Mol Cell Biol, 2: 21-32.

Oikawa S, Kawanishi S 1999. Site-specific DNA damage at GGG sequence by oxidative stress may accelerate telomere shortening. FEBS Lett, 453: 365-368.

Perry P, Wolff S 1974. New Geimsa method for the differential staining of sister chromatids. Nature, 251: 156-158.

Popp W, Vahrenholz C, Schmieding W, Krewet E, Norpoth K 1991. Investigation of the frequency of DNA strand breaking and cross-linking and of sister chromatid exchange in the lymphocytes of electric welders exposed to chromium- and nickel-containing fumes. Int Arch Occup Environ Health, 63: 115-120.

Rajvanshi MI, Hydrabadi VR, Rao MV, Chinoy NJ 2004. Role of a herbal antioxidant on nickel induced genotoxicity in human blood cultures. In: PP Reddy, C Manohara, A Jyothy (Eds.). Trends in Cytology and Genetics.Hyderabad. Pp. 217-224.

Rao MV, Tiwari H 2006.Amelioration of melatonin of chromosomalanomalies induced by arsenic and/or fluoride in human blood lymphocyte culture. Fluoride, 39(4): 251-256.

Rao MV, Jhala DD, Chettiar SS, Patel A, 2007. Evaluation of curcumin as potential herbal agent for mitigation of nickel and chromium induced micronuclei in human blood cultures. Curr Trends in Biot Pharm, (In press).

Saretzki G, Von ZT 2002. Replicative aging, telomeres, and oxidative stress. Ann. NY Acad Sci, 959:2429.

Shishodia S, Potdar P, Gairola CG, Aggarwal BB 2003. Curcumin (diferuloylmethane) down-regulates cigarette smoke-induced NF-kappaB activation through inhibition of IkappaBalpha kinase in human lung epithelial cells: correlation with suppression of COX-2, MMP-9 and cyclin D1. Carcinogenesis, 24(7): 1269-1279.

Sitte N, Saretzki G, Von ZT 1998. Accelerated telomere shortening in fibroblasts after extended periods of confluency. Free Radic Biol Med, 24: 885-893.

Stern RM, Hansen K, Madsen AF, Olsen KM 1988. In vitro toxicity of welding fumes and their constituents. Environ Res, 46: 168-180.

Townsley FM, Ruderman JV 1998. Proteolytic ratchets that control progression through mitosis. Trends Cell Biol, 8: 238-244.

Visintin R, Prinz S, Amon A 1997. CDC20 and CDH1: a family of substrate-specific activators of APC-dependent proteolysis. Science (Wash. DC), 278: 460463 .

Von ZT, Saretzki G, Docke W, Lotze C 1995. Mild hyperoxia shortens telomeres and inhibits proliferation of fibroblasts: a model for senescence? Exp Cell Res, 220: 186-193.

Wenwei H, Zhaohui F, Moon-shong T 2004. Nickel (II) enhances benzo[a]pyrene diol epoxide-induced mutagenesis through inhibition of nucleotide excision repair in human cells: a possible mechanism for nickel (II)-induced carcinogenesis. Carcinogenesis, 25(3): 455-462. 